\title{
Maize silage for dairy cows: mitigation of methane emissions can be offset by land use change
}

\author{
T. V. Vellinga $\cdot$ I. E. Hoving
}

Received: 7 December 2009/Accepted: 24 September 2010/Published online: 14 October 2010

(C) The Author(s) 2010. This article is published with open access at Springerlink.com

\begin{abstract}
Increasing the digestibility of cattle rations by feeding grains and whole plant silages from maize have been identified as effective options to mitigate greenhouse gas emissions. The effect of ploughing grassland for maize crops have not been taken into account yet. A intensive dairy farm is used as an example to demonstrate the trade offs by this type of land use change when more maize silage is fed to dairy cows. The model DAIRY WISE has been used to calculate the mitigation by the changed ration, the Introductory Carbon Balance Model to calculate the changes in soil organic carbon and nitrogen caused by ploughing grassland for maize crops. The losses of soil carbon and the loss of sequestration potential are much larger than the annual mitigation by feeding more maize. The ecosystem carbon payback time defines the years of mitigation that are needed before the emissions due to land use change are compensated. For ploughing grassland on sandy soils, the carbon payback time is 60 years. A higher global warming potential for methane can reduce the carbon payback time with $30 \%$. Ploughing clay soils with a higher equilibrium level of soil organic matter increases the payback time by maximally $70 \%$. The payback times occur only in the case of permanent maize cropping, grass
\end{abstract}

T. V. Vellinga $(\varangle) \cdot$ I. E. Hoving

Wageningen UR Livestock Research, Lelystad,

The Netherlands

e-mail: theun.vellinga@wur.nl maize rotations cause annual losses of nitrous oxide that are larger than the mitigation by feeding more maize.

Keywords Mitigation - Land use change · Carbon sequestration $\cdot$ Modelling

\section{Introduction}

Livestock contributes significantly to the total greenhouse gas (GHG) emissions (Steinfeld et al. 2006), with land use change, enteric fermentation from ruminants and manure management as the largest contributors.

Mitigation is necessary to reduce these emissions. Several mitigation options for intensive dairy farming have been mentioned focusing on reduction of nitrous oxide emissions by reducing fertilizer use and reduction of methane emissions by changing the animals diet to reduce enteric fermentation (Schils et al. 2005; Lovett et al. 2006; Olesen et al. 2006). Manure management including anaerobic digestion of manure is an interesting options for other sectors, such as beef cattle, pigs and poultry as well (Carrere et al. 2009).

Mitigation can be counteracted by trade offs (van Groenigen et al. 2008). They illustrated this for reducing $\mathrm{N}$-losses and found possible trade offs in methane emission from manure storage. Increased nitrous oxide emissions are discussed as a potential 
trade off of carbon sequestration and no tillage systems (Desjardins et al. 2005; Johnson et al. 2007). The loss of soil carbon as a consequence of land use change has been recognized as an important trade off for production of biofuels (Fargione et al. 2008) and for deforestation due to the use of soy as a concentrate component in intensive livestock production systems (Wassenaar et al. 2007; Garnett 2009). At the same moment the importance of soil carbon stocks in reducing greenhouse gas emissions has been emphasized (IPCC 2007; Smith 2008).

Because methane from enteric fermentation is an important contributor to the GHG emissions on dairy farms, much effort is put on changing the animals ration to reduce these emissions. Increase of the feed digestibility by using more feed crops as grains and whole plant silages from e.g. maize have been identified as effective mitigation options (Schils et al. 2007b; Beauchemin et al. 2008). Silage maize also played an important role in the last decades in reducing the $\mathrm{N}$ content of the cattle's ration and increasing the overall digestibility of the ration (Aarts et al. 1999; Luo et al. 2008). The increase in maize area in The Netherlands in the last part of the twentieth century caused a large increase in GHG emissions by ploughing vast areas of grassland for maize cropping (Vellinga et al. 2004). It is to be expected that a further increase of the area of energy rich feed crops such as maize will at least partly occur at the expense of the grassland area. Ploughing up grassland leads to large losses of soil organic $\mathrm{C}$ and $\mathrm{N}$ (Vellinga et al. 2004; Pineiro et al. 2009) and the aimed reduction of enteric fermentation will have its trade off by the increased emissions by land use change. This effect is similar to what is found in the case of land use change for the production of biofuel crops as soy bean and sugar cane in Brazil, oil palm in South East Asia and corn in the United States of America. The magnitude of the losses of soil organic $\mathrm{C}$ and $\mathrm{N}$ depends on the region, the previous land use and the used crop (Fargione et al. 2008; Pineiro et al. 2009). The use of no-tillage systems is also known to have significant effects on the levels and sequestration rates of soil organic C and N (Grant et al. 2004; Six et al. 2004; Chatskikh et al. 2008). The use of no tillage systems is increasing in North and South America and in Europe as well.

Time plays an important role; land use change occurs once, initiating large emissions for a limited number of years, whereas the mitigation is realized at a constant level every year. (Gibbs et al. 2008) defined the Ecosystem Carbon Payback Time to calculate how many years it takes before the emissions caused by land use change are compensated by the mitigation.

So far, the trade off of land use change and the time it takes to compensate this trade off has not been calculated for mitigation options on intensive dairy farms in North Western Europe, Canada and New Zealand (Schils et al. 2007b; Beauchemin et al. 2008; Luo et al. 2008). It is the goal of this paper to get insight in the cumulative effects over time of changing animal diets as a mitigation option and the nitrous oxide and carbon dioxide emissions from ploughing grassland for feed crops by using conventional tillage and no tillage systems. This insight will be provided by using an example of mitigation and land use change on an intensive dairy farm in The Netherlands.

\section{Materials and methods}

A farm model for calculating mitigation options

In the industrialized countries, models have been developed to simulate farm processes and calculate the related emissions to the environment (Schils et al. 2005, 2007b). The model DAIRYWISE (Schils et al. 2007a) includes an extensive GHG-module (Schils et al. 2007b). It is a full accounting model, taking interactions between fertilization, grazing, and feeding strategy into consideration. An economic module calculates the financial results. The GHG module calculates methane emissions and direct and indirect emissions of nitrous oxide. Also calculated are emissions of carbon dioxide from on farm energy use and from the off farm energy use related to the production and transport of concentrates and fertilizers. Emissions and energy use related to crop production of external feed, by products and concentrate components are not incorporated in the model. The model has been validated for Dutch dairy farms on sand, clay and peat soils (Schils et al. 2007a). Calculations with DAIRYWISE are a good example of calculating the cost effectiveness of mitigating greenhouse gas emissions on intensive dairy farms in Northwestern Europe. 
Energy use of machinery was calculated from the calculated number of silage cuts, manure spreading, the use of contractors, milking equipment and from indirect sources as energy for fertilizer production and energy for transport of external inputs to the farm.

All data on grassland use, feed production, feed intake, inputs of external feed, by products and concentrates, manure production and energy use were used to calculate nitrogen losses via nitrate leaching, ammonia volatilization and $\mathrm{N}_{2} \mathrm{O}$ emissions. All technical results and the nitrogen fluxes are used to calculate the emissions of $\mathrm{CH}_{4}, \mathrm{~N}_{2} \mathrm{O}$ and carbon dioxide (Schils et al. 2007b).

The direct $\mathrm{N}_{2} \mathrm{O}$ emissions from manure are the same as are used in Miterra (Velthof et al. 2009). The nitrogen $(\mathrm{N})$ excretion by animals is based on the $\mathrm{N}$ concentration in feed, the feed intake and the digestibility. The ammonia emission is based on the $\mathrm{N}$ excretion, the amount of manure and the type of storage. The $\mathrm{N}_{2} \mathrm{O}$ emission of applied manure and chemical fertilizer are based on the applied $\mathrm{N}$, corrected for ammonia volatilization, the soil type (sand/clay or peat) and the drainage (ranging from wet to dry in spring). Soil type and drainage are also the determining factors for $\mathrm{N}_{2} \mathrm{O}$ losses from crop residues. Histosols have $\mathrm{N}_{2} \mathrm{O}$ emissions, based on the oxidation loss of organic matter (Van Der Hoek et al. 2005). $\mathrm{N}_{2} \mathrm{O}$ losses by grassland renovation are related to soil type, drainage, period (spring, autumn) and type (ploughing or sodseeding) of grassland renovation. Related $\mathrm{N}_{2} \mathrm{O}$ losses from $\mathrm{N}$ imports via fertilizers are calculated. $\mathrm{CH}_{4}$ emission from enteric fermentation is based on the total feed intake, the emission from manure storage is based on storage type and coverage. Both $\mathrm{CH}_{4}$ emissions are calculated in the same way as in the National Inventory Reports (Smink et al. 2004). Based on this, the model is sensitive to soil type and drainage, grazing systems, fertilizer use, manure storage, feed quality and grassland renovation. Changes in carbon stocks by grassland renovation and carbon sequestration in permanent grassland are not incorporated in the model yet. Energy use for transport and processing concentrates is incorporated, but the emissions related to cultivation of the externally produced feed are not in the model. This means that the model cannot be considered as a full Life Cycle Assessment.
Effects of land use change on $\mathrm{C}, \mathrm{N}$ and GHG emissions

Soil carbon content is affected by the type of land use. There are large differences in soil organic carbon (and nitrogen) contents between grassland and arable soils (Conant et al. 2005). Grassland management affects the addition of carbon to the soil and hence the level of soil organic carbon (Soussana et al. 2007). Most of the grassland on intensive dairy farms is used in the same way, i.e. a combination of grazing and cutting with limited differences in the level of fertilization. We assume that this limited difference will not affect soil organic carbon significantly.

The Introductory Carbon Balance Model (ICBM) (Andren and Katterer 1997; Katterer and Andren 1999) is used to quantify the amounts of $\mathrm{C}$ and $\mathrm{N}$ which are accumulated or released under grassland and arable land, by simulating soil organic $\mathrm{N}$ turnover and assuming a constant $\mathrm{C}$ to $\mathrm{N}$ ratio in soil organic matter. They defined two organic $\mathrm{C}$ pools: young and old, with a high and low decomposition rate parameter, respectively, for $\mathrm{C}$ mineralisation and a humification parameter for throughput of mineralised $\mathrm{C}$ from the young to the old pool. The pools have been redefined for the ICBM as follows: a relatively unstable organic N-pool (young) and a stable organic $\mathrm{N}$-pool (old), with their own decomposition rates and humification factor were defined as in Fig. 1. The decomposition rate of the young pool is affected by conventional tillage, a factor 3 is used between grassland and cropland. The model is still in use for calculating carbon stocks (Katterer et al. 2004; Bolinder et al. 2008).

The ICBM has been applied and validated by Vellinga et al. (2004) for calculating soil organic carbon pools with the focus on the contrast between grassland and arable land. In this study, a standard C to $\mathrm{N}$ ratio of $1-15$ will be used for sandy soils (Hassink 1994). The $\mathrm{C}$ to $\mathrm{N}$ ratio remains almost constant during changes in carbon stocks (Conant et al. 2005).

The process of decrease of soil organic $\mathrm{C}$ and $\mathrm{N}$ plays a role on two levels when grass/arable rotations are practiced (Vellinga et al. 2004). The first one is the long term process of decades; land use change implies another equilibrium level of Soil Organic Carbon (SOC) (Conant et al. 2007), with large changes in the amounts of SOC and Soil Organic 


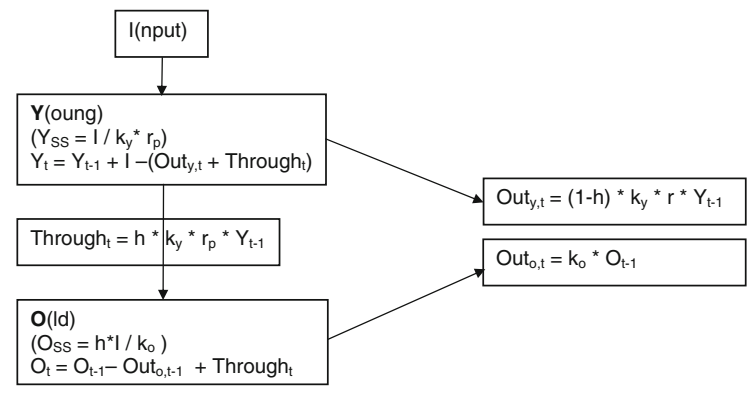

Fig. 1 Structure of the Introductory Carbon Balance Model $(I C B M)$ by Andren and Kätterer (1997). State variables are $\mathrm{Y}_{\mathrm{t}}$ and $\mathrm{O}_{\mathrm{t}}$, representing a young, unstable and an old, stable organic $\mathrm{N}$ pool respectively $\left(\mathrm{kg} \mathrm{ha}^{-1}\right)$ and their steady state condition $\left(\mathrm{Y}_{\mathrm{ss}}\right.$ and $\mathrm{O}_{\mathrm{ss}}$, respectively, $\left.\mathrm{kg} \mathrm{ha}^{-1}\right), \mathrm{k}_{\mathrm{y}}$ and $\mathrm{k}_{\mathrm{o}}$ are decomposition rates for the young and old pool respectively $\left(\mathrm{kg} \mathrm{ha}^{-1}\right.$ year $\left.^{-1}\right), \mathrm{h}$ is the humification factor $(-), \mathrm{r}_{\mathrm{p}}$ is the "ploughing" coefficient (-). Through $h_{t}$ is an internal flux, the throughput of $\mathrm{N}$ from the young to the old pool $\left(\mathrm{kg} \mathrm{ha}^{-1}\right.$ year $\left.^{-1}\right)$. External fluxes are Out $_{\mathrm{y}, \mathrm{t}}$, Out $\mathrm{o}, \mathrm{t}$, the $\mathrm{N}$ release by the young and old $\mathrm{N}$ pools respectively $\left(\mathrm{kg} \mathrm{ha}^{-1}\right.$ year $^{-1}$ ). $t$ represents time (year)

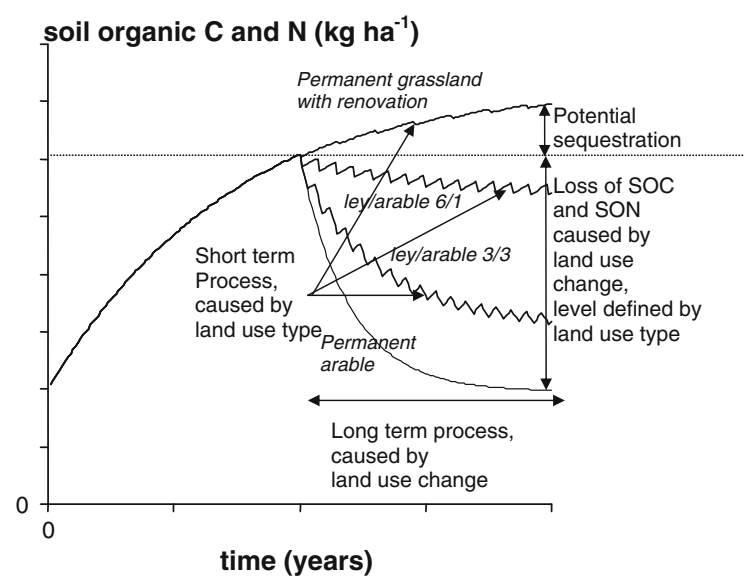

Fig. 2 Patterns of soil organic $\mathrm{C}$ and $\mathrm{N}$ accumulation and losses on permanent grassland over time for situations with regular renovation by ploughing and patterns of soil organic $\mathrm{C}$ and $\mathrm{N}$ decrease when 50 year old grassland is ploughed and converted to arable or ley arable systems with different rotational length. "Actual" losses from conversion, rotation and renovation and a so-called "potential" loss are distinguished. The latter represents the continued $\mathrm{N}$ accumulation until equilibrium conditions on grassland are reached

Nitrogen (SON) (Fig. 2). The second process plays on the short term of a few years, it is the loss of soil organic carbon and nitrogen due to the land use type: the release of soil organic matter during the short arable phase and the sequestration of $\mathrm{C}$ and $\mathrm{N}$ during the subsequent short grassland phase, leading to a deviation around the long term equilibrium. The long term equilibrium level and the deviation around it depend both on the number of grassland and arable years in the rotation.

In the long term process, the loss of soil organic carbon and nitrogen both should be seen as a loss, because the land use change causes a new equilibrium. In the short term process, the loss of carbon can be seen as belonging to the short carbon cycle. It is lost in the arable years and sequestered in the grassland years. Nitrogen however, will be lost to the environment, in part as nitrous oxide. The addition in the subsequent grassland phase via manure or fertilizer is subject to emissions of nitrous oxide. So nitrogen emissions in ley arable rotations should be considered as a loss (Vellinga et al. 2004).

\section{The effect of no tillage systems}

The use of no tillage affects carbon sequestration, nitrous oxide and methane emissions. So, a good evaluation of no tillage needs a full GHG accounting approach (Six et al. 2004; Batlle-Bayer et al. 2010)Extra carbon sequestration ranging from 97 to $1,000 \mathrm{~kg} \mathrm{C}$ per hectare per year have been reported (Six et al. 2004; Chatskikh et al. 2008; Batlle-Bayer et al. 2010). The effect of no tillage on nitrous oxide depends on the region and the related climatic conditions. Smith et al. (2010) introduced a tillage factor, ranging from 0.8 to 1.1 in the calculation of the emission factor for nitrous oxide.

To simulate the difference in carbon sequestration between conventional and no tillage, the decomposition rate of no tillage is calibrated on the basis of Danish data (Chatskikh et al. 2008). The rate is 1.5 times higher compared to grassland, whereas the decomposition rate of conventional tillage is 3 times higher. The emission factor for nitrous oxide is kept constant, due to the variation found in literature (Johnson et al. 2005; Smith et al. 2010). The nitrous oxide emission is only affected by the change in released nitrogen of no tillage compared to conventional tillage.

The experiences with direct drilling of maize are limited. In the case of preparing grassland for feed crops, we assume that small strips of grass are cultivated to sow maize. The fraction of these strips is $16 \%$ of the total grassland area. The remaining $84 \%$ of the grassland is kept intact. This crop/grassland 
ratio of $16 / 84$ is used to calculate the emissions of a reduced tillage system. After 1 or 2 years of maize crops in this partly cultivated grassland, the whole grass sward has to be renovated in autumn, after removal of the maize crop. We assumed a reduced tillage method for grassland renovation as suggested by Roberts et al. (1989). The extra emissions of $\mathrm{CO}_{2}$ and $\mathrm{N}_{2} \mathrm{O}$ are assumed to be equal to grassland renovation in spring as defined by Vellinga et al. (2004). Many assumptions have to be made for this section. The calculation results can therefore only be considered as an indication.

Example: intensive dairy farm

To illustrate the effects of an increasing proportion of maize in the animals' ration on the changes GHG emissions from farm activities and from land use change, we selected data from a commercial farm in The Netherlands. The farm had been part of a pilot project to get insight in GHG emissions on commercial intensive dairy farms, in the farmers preferences for mitigation options and in the cost-effectiveness of these options on commercial farms. The increase of maize in the animals ration was the second preferred option by the farmers, the increase of the milk production per cow was the first.

The farm in the example is located in the centre of The Netherlands on a well drained sandy soil with a low susceptibility for drought. Data about livestock, land use, milk production, inputs of fertilizers, concentrates and bought roughages were collected. A condensed version of the questionnaire is in Table 1 . The information from the questionnaire was used as input in the model. Production and quality of fresh grass and grass silage were calculated in a grassland utilization simulation with stocking rate, animal feed intake, grazing system, fertilization level, soil type and drainage as key parameters. Intake of fresh grass, grass and maize silage were calculated from the input values milk production per cow, grazing system, supplementation, and concentrate use and from the calculated energy content of fresh grass and from the calculated amounts and qualities of grass and maize silage. The amount and quality of manure was calculated from total intake of feed and the nutrients in the feed. The technical results of this farm are shown in Table 2.

The selected farmer wanted to increase the maize area by 4 ha (Table 2). This increase in the maize
Table 1 A condensed list of parameters in the questionnaire for the farmers

\begin{tabular}{ll}
\hline Parameter & Unit \\
\hline Name farmer & - \\
Milk produced & $\mathrm{kg}$ \\
Quota fat content & $\%$ \\
Number of cows, calves, heifers & - \\
Milk/cow & $\mathrm{kg} / \mathrm{cow}$ \\
Milk: fat, protein, urea & $\%, \%, \mathrm{mg} / \mathrm{kg}$ \\
Area grass, maize, other feed crops & $\mathrm{ha}$ \\
Area ownership, rented land, & $\mathrm{ha}, \mathrm{ha}(€)$ \\
paid rent & - \\
Soil type and drainage & $\%$ \\
Winter feed, share of grass & \\
and maize silage &,$- \mathrm{kg} / \mathrm{cow}$ \\
Dairy cows: grazing & \\
system + supplementation & - \\
Young stock: grazing system & $\mathrm{kg} \mathrm{DM} / \mathrm{farm}$ \\
Input of roughage & $\mathrm{Kg} / \mathrm{farm}$ \\
(bought maize and grass silage) & $\mathrm{each} \mathrm{ha,} € / \mathrm{ha}$ \\
Input of by-products & $\mathrm{kg} \mathrm{DM} / \mathrm{farm}$ \\
Input concentrates per & $\mathrm{kg} / \mathrm{cow}$ \\
cow incl. young stock & \\
Input/output manure & $\mathrm{P}$ Prom chemical fertilizer \\
Work done by contractor, & \\
\hline &
\end{tabular}

area is enough to realize a reduction in GHG emissions per $\mathrm{kg}$ milk. The farm size and the remaining grassland area are large enough to explore different scenarios for land use change as e.g. different grass maize rotations. The size of the farm of 70 ha in total and the related change of 4 ha will only slightly reduce the average number of silage cuts per hectare from 3.0 to 2.8 per year (Table 2). It allows to use the ICBM model and not to take changes in grassland management into consideration.

Increasing the maize area by 4 ha led to a calculated reduction of emissions per $\mathrm{kg}$ milk of $11 \mathrm{~g} \mathrm{CO}_{2}$-equivalents. For the farm level, a total annual reduction of $11,055 \mathrm{~kg}$ of $\mathrm{CO}_{2}$-equivalents was calculated.

Land use change scenarios

The increase in maize area on the farm can be realized in different ways. The first and most simple 
Table 2 The parameters of the farm on sandy soil, used as an example p.m. pro memori will be calculated in this paper

\begin{tabular}{|c|c|c|}
\hline & Baseline & Extra maize \\
\hline Farm size (ha) & 70 & 70 \\
\hline Grassland (ha) & 56 & 52 \\
\hline Maize (ha) & 14 & 18 \\
\hline Soil type & Sand & Sand \\
\hline Dairy cows (-) & 120 & 120 \\
\hline Calves, $0-1$ year $(-)$ & 4 & 4 \\
\hline Heifers, 1-2 year (-) & 5 & 5 \\
\hline Milk production $\left(\mathrm{kg} \mathrm{cow}^{-1}\right.$ year $\left.^{-1}\right)$ & 8,491 & 8,491 \\
\hline Milk production per hectare $\left(\mathrm{kg} \mathrm{ha}^{-1}\right.$ year $\left.^{-1}\right)$ & 14,571 & 14,571 \\
\hline Milk farm $\left(\mathrm{kg} \mathrm{year}^{-1}\right)$ & $1,018,948$ & $1,018,920$ \\
\hline Milk fat content $\left(\mathrm{g} \mathrm{kg}^{-1}\right)$ & 42.6 & 42.6 \\
\hline Milk protein content $\left(\mathrm{g} \mathrm{kg}^{-1}\right)$ & 34.1 & 34.1 \\
\hline \multicolumn{3}{|l|}{ Feed intake $\left(\mathrm{kg} \mathrm{DM} \mathrm{cow}^{-1}\right)$} \\
\hline Fresh grass & 481 & 570 \\
\hline Silage (grass, maize) & 4,044 & 4,106 \\
\hline Concentrates and by products & 2,926 & 2,798 \\
\hline $\mathrm{N}$ input from fertilizer $\left(\mathrm{kg} \mathrm{ha}^{-1}\right)$ & 50 & 54 \\
\hline Average number of silage cuts $\left(\mathrm{ha}^{-1}\right.$ year $\left.^{-1}\right)$ & 3.01 & 2.82 \\
\hline Production of grass silage $(\times 1,000 \mathrm{~kg})$ & 345 & 302 \\
\hline Production of maize silage $(\times 1,000 \mathrm{~kg})$ & 173 & 220 \\
\hline GHG emission farm (kg CO 2 -equivalents) & 928,995 & 917,940 \\
\hline GHG emission per kg milk ( $\mathrm{g} \mathrm{CO}_{2}$-equivalents $\mathrm{kg}^{-1}$ ) & 0.912 & 0.901 \\
\hline $\mathrm{CO}_{2}\left(\mathrm{~kg} \mathrm{CO}\right.$-equivalents $\mathrm{kg}^{-1}$ milk $)$ & 0.348 & 0.340 \\
\hline $\mathrm{N}_{2} \mathrm{O}\left(\mathrm{kg} \mathrm{CO}_{2}\right.$-equivalents $\mathrm{kg}^{-1}$ milk) & 0.108 & 0.108 \\
\hline $\mathrm{CH}_{4}\left(\mathrm{~kg} \mathrm{CO}\right.$-equivalents $\mathrm{kg}^{-1}$ milk) & 0.456 & 0.453 \\
\hline Emissions from land use and land use change & p.m. & p.m \\
\hline Emission change ( $\mathrm{kg} \mathrm{CO}_{2}$-equivalents $\mathrm{kg}^{-1}$ milk) & & -0.011 \\
\hline Emission change farm (kg CO 2 -equivalents) & & $-11,055$ \\
\hline Change in farm income $(€)$ & & 664 \\
\hline
\end{tabular}

option is to plough 4 ha of grassland and permanently grow maize (scenario M0).

The second option is the rotation grass and maize on the same area. Every year 4 ha of maize are grown on ploughed grasslands. The maize is grown for 1 or 2 years on the same land, after that it returns back to grassland and other grassland is ploughed to grow maize. Grassland is ploughed after a number of years and followed by 1 or 2 years of maize. After that the land is converted into grassland again. The total land area for such a rotation depends on the number of grassland and maize years. When we take for example a cycle of 10 years, in which grassland is ploughed after 9 years and followed by 1 year of maize and returns to grassland again, a total area of 40 ha is involved. This is scenario M1 (Table 3). When we have 2 years of maize, in combination with 8 years of grassland, an area of 20 ha is involved. This scenario M2 (Table 3). The remaining permanent grassland in the scenarios M0, M1 and M2 is 52, 16 and 36 ha, respectively and will be renovated every 10 years. Regular grassland renovation by reseeding is a common practice in The Netherlands (Vellinga et al. 2004).

The changes in carbon stocks will be evaluated after a period of 70 years. The IPCC uses a time horizon of 20 years (IPCC 2006), after that period the changes in soil organic carbon and nitrogen are 
Table 3 The land use in the case of the baseline and in the case of the scenarios M0, M1 and M2, when 4 ha maize extra is grown at the farm at the expense of the grassland area

\begin{tabular}{lllllc}
\hline Scenario & $\begin{array}{l}\text { Permanent } \\
\text { grassland }\end{array}$ & $\begin{array}{l}\text { Permanent } \\
\text { maize }\end{array}$ & $\begin{array}{l}\text { Grass in } \\
\text { rotation }\end{array}$ & $\begin{array}{l}\text { Maize in } \\
\text { rotation }\end{array}$ & $\begin{array}{l}\text { Rotation frequency } \\
\text { years grass/ } \\
\text { years maize }\end{array}$ \\
\hline Baseline & 56 & 14 & 0 & 0 & - \\
M0 & 52 & 18 & 0 & 0 & - \\
M1 (CT and NT) & 16 & 14 & 36 & 4 & $9 / 1$ \\
M2 (CT and NT) & 36 & 14 & 16 & 4 & $8 / 2$ \\
\hline
\end{tabular}

expected to be limited. Calculations with the ICBM model show that after 70 years the equilibrium situation is almost reached and that in the subsequent 100 years the soil organic nitrogen and carbon contents will change by about $3 \%$.

Calculating changes in soil organic carbon and nitrogen

Because the land use history of the farm that is used for illustration is not exactly known, the age of all grassland on the farm is set at 50 years. This is a common situation of specialized dairy farms on the sandy soils, where mixed farms since about 1950 started to change to specialized dairy farms. The use of maize as a feed crop increased strongly in the period from 1975 to 1985 (Vellinga et al. 2004). We assume that this maize has been grown on the same land for a long time. The amounts of SON and SOC have been calculated for the starting point of the mitigation. From that point the development of the SON and SOC are calculated based on the different scenarios of land use changes. The differences between the starting value and the final values are considered after a period of 70 years to be caused by the land use change scenarios.

In the case of grassland renovation, the $\mathrm{N}$ released from the grass sward is assumed to be taken up by the new grass sward immediately. Only the reduction in SON during the short phase of grassland renovation is assumed to be lost. In the case of the grass/maize rotations, the loss consists of decreased SON and N from the grass sward. Part of the released $\mathrm{N}$ can be taken up by the newly sown crop and fertilizer inputs can be reduced by 100 and $25 \mathrm{~kg} \mathrm{~N} \mathrm{ha}^{-1}$ in the first and second year after ploughing, respectively (Van Dijk 1997). In the case of no tillage systems, fertilizer input is not reduced.

\section{Results}

Long term losses of soil organic $\mathrm{C}$ and $\mathrm{N}$ with conventional tillage

At the start of all scenarios 4 ha are ploughed and maize is grown. In the scenario M0, these hectares will be used permanently to grow maize and the decrease in soil organic nitrogen and carbon is large (Table 4). The total losses of SON and SOC per hectare are lower in the situations of grass/maize rotations (Table 4). In the case of 9 years grassland and 1 year maize, the loss of SON and SOC are limited, 217 and 3,251 $\mathrm{kg}$ per hectare, respectively.

The changes in SON and SOC per hectare from Table 4 are combined with the hectares from Table 3 to total changes at the farm level (Table 5). In the baseline, the SON and SOC increase with 10,200 and $153,000 \mathrm{~kg}$ at farm level respectively. The amounts of soil organic $\mathrm{N}$ and $\mathrm{C}$ decrease to a limited extent in the situation where 4 ha of grassland is used for maize on a permanent basis (the M0 scenario), 1,100 and $17,000 \mathrm{~kg}$ respectively. In the situation where maize is grown in rotation with grass (the M1 and M2 scenarios), the changes in SON and SOC are more negative at farm level compared to field level. This is caused by the larger number of hectares that is involved in the rotations (Table 3 ).

The differences in stocks of SON and SOC between the baseline and the $\mathrm{M}$-scenarios are the consequence of the growth of 4 ha maize extra on the farm. In case of soil organic carbon this difference is in part an actual loss compared to the starting point and partly a missed sequestration after the start of the mitigation. The missed sequestration is not a real loss, but it would have withdrawn $\mathrm{CO}_{2}$ from the atmosphere. But in the case of the $\mathrm{N}$ changes we have to choose another approach. The actual loss of SON 
Table 4 Changes in amounts of soil organic nitrogen and carbon in $\mathrm{kg}$ per hectare over a period of 70 years, when a new equilibrium has been realized on a sandy soil

\begin{tabular}{|c|c|c|c|c|}
\hline Land use & $\begin{array}{l}\text { SON at start } \\
\left(\mathrm{kg} \mathrm{ha}^{-1}\right)\end{array}$ & $\begin{array}{l}\text { SON after } 70 \text { years } \\
\text { (new equilibrium) } \\
\left(\mathrm{kg} \mathrm{ha}^{-1}\right)\end{array}$ & $\begin{array}{l}\text { Change } \\
\text { in SON } \\
\left(\mathrm{kg} \mathrm{ha}^{-1}\right)\end{array}$ & $\begin{array}{l}\text { Change } \\
\text { in SOC } \\
\left(\mathrm{kg} \mathrm{ha}^{-1}\right)\end{array}$ \\
\hline Permanent grassland, all scenarios & 5,340 & 5,544 & 204 & 3,067 \\
\hline Permanent maize old, all scenarios & 2,483 & 2,393 & -90 & $-1,344$ \\
\hline \multicolumn{5}{|l|}{ Conventional tillage } \\
\hline Permanent maize new, scenario M0, CT & 5,340 & 2,711 & $-2,628$ & $-39,426$ \\
\hline Grass/maize, scenario M1, CT & 5,340 & 5,123 & -217 & $-3,251$ \\
\hline Grass/maize, scenario M2, CT & 5,340 & 4,601 & -738 & $-11,072$ \\
\hline \multicolumn{5}{|l|}{ No tillage } \\
\hline Permanent maize new, scenario M0, NT & 5,340 & 2,920 & $-2,420$ & $-36,293$ \\
\hline Grass/maize, scenario M1, NT & 5,340 & 5,461 & 121 & 1,822 \\
\hline Grass/maize, scenario M2, NT & 5,340 & 5,185 & -155 & $-2,318$ \\
\hline
\end{tabular}

Values in the equilibrium situation are the averages over the rotation periods of 10 years. C/N ratio is 15 (Hassink 1994)

Table 5 The total losses of soil organic carbon and nitrogen and the related emissions of $\mathrm{CO}_{2}$ and $\mathrm{N}_{2} \mathrm{O}$ at farm level after a period of 70 year

\begin{tabular}{|c|c|c|c|c|c|c|c|}
\hline & \multirow[t]{2}{*}{ Baseline } & \multicolumn{3}{|c|}{ Conventional tillage } & \multicolumn{3}{|c|}{ No tillage } \\
\hline & & M0 & M1 & M2 & M0 & M1 & M2 \\
\hline \multicolumn{8}{|l|}{ SOC (1,000 kg C) } \\
\hline Start & 5,007 & 5,007 & 5,007 & 5,007 & 5,007 & 5,007 & 5,007 \\
\hline End & 5,160 & 4,990 & 4,907 & 4,877 & 5,002 & 5,110 & 5,052 \\
\hline Change of SOC & 153 & -17 & -100 & -130 & -5 & 103 & 45 \\
\hline Rel. to baseline & & -170 & -253 & -283 & -157 & -50 & -108 \\
\hline \multicolumn{8}{|l|}{$\mathrm{SON}(1,000 \mathrm{~kg} \mathrm{~N})$} \\
\hline Start & 333.8 & 333.8 & 333.8 & 333.8 & 333.8 & 333.8 & 333.8 \\
\hline End & 344.0 & 332.6 & 327.1 & 325.1 & 333.5 & 340.6 & 336.8 \\
\hline Change of SON & 10.2 & -1.1 & -6.7 & -8.7 & -0.3 & 6.9 & 3.0 \\
\hline \multicolumn{8}{|l|}{ GHG emission ( $1,000 \mathrm{~kg} \mathrm{CO}_{2}$ equivalents) } \\
\hline $\mathrm{N}_{2} \mathrm{O}$ & & 17 & 101 & 132 & 5 & -105 & -46 \\
\hline $\mathrm{CO}_{2}$ & & 623 & 927 & 1,037 & 577 & 183 & 395 \\
\hline Total & & 640 & 1,028 & 1,169 & 582 & 78 & 349 \\
\hline \multicolumn{8}{|l|}{ Gram $\mathrm{CO}_{2}$-equivalents $/ \mathrm{kg}$ milk } \\
\hline Period $=70$ year (equilibrium) & & 9 & 14 & 16 & 8 & 1 & 5 \\
\hline Period $=20$ year $($ IPCC guidelines $)$ & & 31 & 50 & 57 & 29 & 4 & 17 \\
\hline
\end{tabular}

Emissions expressed per $\mathrm{kg}$ of milk and for time frames of 20 years (IPCC) and 70 years (equilibrium)

leads to nitrous oxide emissions. The potentially sequestered $\mathrm{N}$ would not have been withdrawn from $\mathrm{N}_{2} \mathrm{O}$ from the atmosphere, but added to the $\mathrm{SON}$ complex via fertilization with manure or industrial fertilizers. So in the case of $\mathrm{N}$ only the decrease of SON compared to the starting point of the mitigation must be taken into account.
The total GHG emissions at the farm level are the lowest in the M0 scenario with $640,000 \mathrm{~kg} \mathrm{CO}$ equivalents and are the highest in the M1 scenario with $1,169,000 \mathrm{~kg} \mathrm{CO}_{2}$ equivalents (Table 5).

When these total losses are expressed per $\mathrm{kg}$ milk we used two options. We divided the total loss through the whole period in which the losses were 
formed, which is 70 years. The other option is to use the IPCC standard of 20 years for land use change (IPCC 2006). In the situation with a timeframe of 70 years, GHG emissions range between 9 and $16 \mathrm{~g}$ $\mathrm{CO}_{2}$-equivalents per $\mathrm{kg}$ milk. In the IPCC timeframe, the GHG emissions range between 31 and $57 \mathrm{~g}$ per $\mathrm{kg}$ milk.

Annual GHG emissions related to the land use type

In the case of the grass/maize rotations also losses occur when the grassland is ploughed for a 1 or 2 year period with maize. The annual losses consist of $\mathrm{N}_{2} \mathrm{O}$ emissions only, as is explained in material and methods.

The GHG emissions in the case of grassland renovation are $1,507 \mathrm{CO}_{2}$ equivalents per hectare (Table 6). The losses during the grass/maize rotations are considerably higher, from almost 5,500 to about $9,000 \mathrm{~kg}$ per hectare per year.

These annual emissions are totalized to the farm level, taking into account the areas from Table 3, the results are shown in Table 7. The losses at M0 are lower than those in the baseline due to the fact that the grassland area for grassland renovation is smaller. In the case of permanent growth of maize, no rotation losses occur. The annual losses of the M1 and M2 scenarios are about almost 26,000 and 18,000 $\mathrm{kg} \mathrm{CO}_{2}$ equivalents at farm level, respectively. The higher loss in the M1 scenario is caused by the fact that only

Table 6 Average annual losses of soil organic nitrogen and nitrogen from the sward ( $\mathrm{kg} \mathrm{N}$ per hectare) and the related GHG emissions ( $\mathrm{kg} \mathrm{CO}_{2}$-equivalents per hectare)

\begin{tabular}{lrc}
\hline Land use & N loss & $\begin{array}{l}\text { GHG } \\
\text { emissions }\end{array}$ \\
\hline Renov10 & 141 & 1,507 \\
Maize old & 0 & 0 \\
Maize new M0, CT & 0 & 0 \\
Grass/maize M1, CT & 569 & 8,573 \\
Grass/maize M2, CT & 365 & 5,492 \\
Maize new, M0, NT & 0 & 0 \\
Grass/maize M1, NT & 160 & 2,863 \\
Grass/maize M2, NT & 236 & 2,004 \\
\hline
\end{tabular}

Extra release of soil and sward $\mathrm{N}$ is partly compensated by reduced fertilizer inputs in the cases of grass/maize rotations and conventional tillage
1 year of maize is grown, with high losses in the first year after ploughing. In the second year after ploughing (in the M2 scenario), the losses are always lower than in the first year. As a consequence, the average loss is lower in the scenarios with two consecutive maize crops at the same field. When the total losses at farm level are divided by the $1,019,000 \mathrm{~kg}$ milk, the annual losses per kg milk are $-1 \mathrm{~g}$ for the M0 scenario, $25 \mathrm{~g}$ for the M1 and $17 \mathrm{~g}$ for the M2 scenarios (Table 7).

When the emissions due to land use change do not play a role anymore, the annual extra GHG emissions, caused by grassland renovation and rotation of grass and maize are the same as presented in the lowest line of Table 7. In that situation the annual emissions from grassland renovation in the scenario without mitigation are $12 \mathrm{~g} \mathrm{CO}_{2}$-equivalents per $\mathrm{kg}$ milk. The M0 scenario has less grassland and thus a $1 \mathrm{~g} \mathrm{CO}_{2}$-equivalents per $\mathrm{kg}$ milk lower emission from grassland renovation than the scenario without mitigation. So the reduction of $11 \mathrm{~g}$ per $\mathrm{kg}$ from Table 2, caused by feeding more maize, is increased by $1 \mathrm{~g}$ to $12 \mathrm{~g} \mathrm{CO}_{2}$-equivalents per $\mathrm{kg}$ milk, compared to the scenario without mitigation. In the case of the grass/ maize rotations, the reduced GHG emission of the extra maize feeding is still completely counteracted by the extra emission of the grass/maize rotations.

\section{Loss of sequestration potential}

The losses of carbon and nitrogen have been calculated related to the baseline situation and to a 70 year period after the start of the mitigation. The large difference between the baseline at the end of the period and the M0 scenario is caused by the continuing carbon sequestration (Fig. 3). At the start of the mitigation period, the grassland renovation causes a slight decrease in soil organic carbon, but after a 10 year period it starts to increase again. The ploughing of 4 ha of grassland for maize in the M0 scenario causes a strong decrease in the soil organic carbon on the farm, leading to a fast decrease of soil carbon in the first years after ploughing. After about 15 years, when this process has slowed down, the carbon sequestration on the other 52 ha is stronger. As a result the total amount of soil organic carbon starts to increase again. The increase rate is slightly lower than in the baseline, due to the difference of 4 ha in grassland area. From this it is clear that a 
Table 7 The annual GHG emissions ( $\mathrm{kg} \mathrm{CO}_{2}$-equivalents) on farm level and per $\mathrm{kg}$ of milk, caused by the grassland renovation on the permanent grassland and grass/maize rotations

\begin{tabular}{lrrrrrrrr}
\hline & & \multicolumn{2}{c}{ Conventional tillage } & & & No tillage \\
& Baseline & M0 & M1 & M2 & & M0 & M1 & M2 \\
\hline Annual GHG emissions at farm level & 11,894 & 11,045 & 37,690 & 29,614 & 11,045 & 14,850 & 15,662 \\
Rel. to baseline & & -850 & 25,796 & 17,720 & -850 & 2,956 & 3,768 \\
Annual GHG emission per kg of milk & 12 & 11 & 37 & 29 & 11 & 15 & 15 \\
Rel. to baseline & & -1 & 25 & 17 & -1 & 3 \\
\hline
\end{tabular}

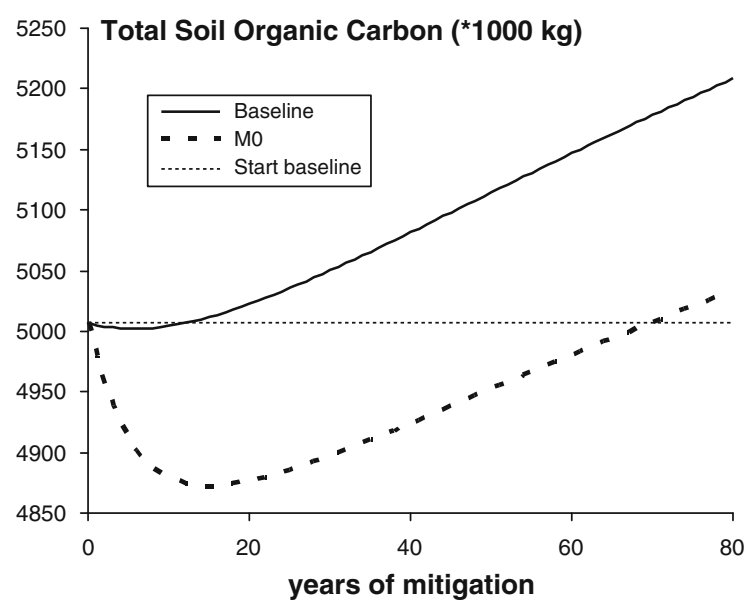

Fig. 3 The change in soil organic carbon at farm level for the baseline (56 ha grassland with grassland renovation and 14 ha maize) and the M0 scenario (52 ha grassland with grassland renovation, 14 ha maize old, 4 ha maize new). Calculations based on the model of Katterer and Andren (1999), adapted by Vellinga et al. (2004)

large mitigation potential is lost by ploughing grassland to grow maize.

The mitigation effect of feeding maize is enhanced by the reduced emissions from grassland renovation in the M0 scenario. So on the long term, when the losses of SON and SOC do not play a role anymore, this mitigation option is attractive. But first the emissions caused by the loss of SON and SOC must be paid back.

After the 70 year period in the calculations, the initially high release of soil organic carbon and nitrogen has slowed down as was shown in Fig. 3. The cumulative difference in greenhouse gas emissions between the baseline and the M0 scenario from Fig. 3 has been calculated and compared with the cumulative mitigation (Fig. 4). The mitigation by feeding maize is supposed to be linear all the time.

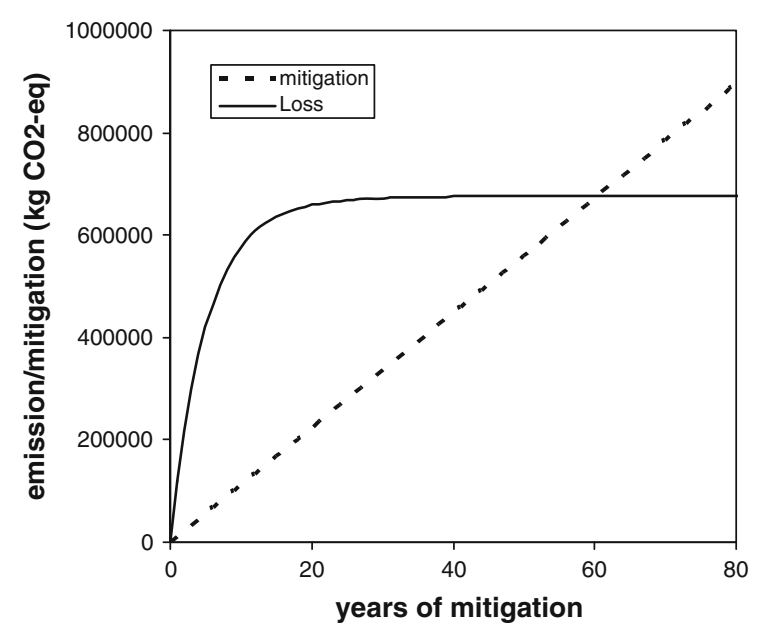

Fig. 4 The cumulative extra greenhouse gas emissions in $\mathrm{CO}_{2}$-equivalents at farm level of the $\mathrm{M} 0$ scenario in relationship to the baseline and the cumulative mitigation by extra maize feeding in the M0 scenario

The bold line shows the cumulative effect of the greenhouse gas emissions caused by the land use change. Although there is 4 ha less grassland renovation in the M0 scenario compared to the scenario without mitigation, the reduced emission is not strong enough to counteract the ongoing small decrease in soil organic matter and to bend the line down and decrease the cumulative greenhouse gas emissions. The cumulative mitigation due to feeding extra maize and the resulting decrease in $\mathrm{CH} 4$ emissions from enteric fermentation is increasing constantly and after about 60 years it is larger than the losses due to land use change. This means that there is a "pay back" time of 60 years. After that time, the extra emission caused by land use change is compensated and the mitigation scenario $\mathrm{M} 0$ is finally contributing to a reduced concentration of greenhouse gases in the atmosphere. 


\section{Discussion}

\section{No tillage systems}

The calculations that are presented in the "Results" section are based on conventional tillage systems. No tillage systems are very common in North and South America and are increasing in Europe. In this study two types of reduced tillage systems have to be considered. The first is the use of no tillage for permanent maize cropping in the M0 scenarios. The effects of no tillage systems in arable crops are studied extensively as discussed before and are incorporated in the ICBM model. Although the sequestration rate under no tillage is $100-1,000 \mathrm{~kg}$ $\mathrm{C}$ per hectare per year higher than under conventional tillage, the pool of SON and SOC decreases sharply when grassland is converted to no tillage arable land. The GHG emissions of no tillage due to loss of SOC and SON are about $10 \%$ less than under conventional tillage (Table 5), while the losses on the grassland part remain the same, because we did not change the technique of grassland renovation.

The second is the use of direct drilling in grass swards. The chosen approach is speculative by assuming that only the cultivated strips are affected and will release SOC and SON at a high rate. But with this assumption it is shown that the loss of SOC and SON and the related GHG emissions are much smaller (Table 5). The $\mathrm{N}_{2} \mathrm{O}$ emissions caused by the rotation of grass and maize is also reduced by about $50 \%$ (Table 6), leading to a $50 \%$ lower emissions per $\mathrm{kg}$ of milk (Table 7). Beside the large uncertainty about the calculation technique, there are many practical problems regarding direct drilling. The grass acts as a competitor for water and nutrients and should be killed by herbicides before maize emergence. The heavy equipment for harvesting maize bears the risk of soil compaction, especially when maize is harvested in fall under suboptimal conditions. The options for direct drilling on heavier clay soils are more limited than on sandy soils.

Mitigation offset by emissions from rotation of grass and maize

The mitigation of methane emissions as a result of extra maize in the animal's ration is partly offset in the M0 scenario with a 70 year timeframe. In all other scenarios it changes into an extra emission of nitrous oxide and carbon dioxide compared to the baseline, due to the greenhouse gas emissions caused by grass/maize rotations. When the loss from land use change has been "paid back", only the losses from grassland renovation and grass/maize rotation remain. In that situation there is a small improvement in the M0 situation. The losses caused by grassland renovation are $11 \mathrm{~g}$ per $\mathrm{kg}$ milk, compared to $12 \mathrm{~g}$ for the baseline. All other scenarios lead to a complete offset of the mitigation in enteric fermentation, even when losses in carbon stocks are not taken into account anymore.

This means that grass/maize rotations or any other rotations of permanent grassland with some years of arable crops should be avoided. Other grass maize rotations like 3 years grass, 3 years maize are in use as well (Aarts et al. 1999). The emissions related to that rotation causes too high losses of nitrous oxide (Vellinga et al. 2004).

Effects of grassland age, soil type and animal category

The loss of SOC and SON by ploughing is affected by the age and the organic matter content of the grassland. Older grassland with higher organic matter contents will lead to increased losses, larger debts and need more time to pay back (Gibbs et al. 2008). On the other hand, the carbon sequestration decreases at higher levels of soil organic matter and there is a maximum level of soil organic matter for every soil type, land use type and related management (Stewart et al. 2007). On the long term the equilibrium organic matter levels of grassland and maize land do not depend on the starting level of soil organic matter, so the sum of actual and potential loss will be the same. But in the case of high organic matter contents at the start of the land use change, the fraction of the actual loss will be larger and the fraction of potential sequestration will be smaller.

The decomposition rates of soil organic matter of grassland and arable land on clay soils are lower than on sandy soils (Katterer and Andren 1999; Vellinga et al. 2004). This leads to a larger difference in levels of soil organic matter between grassland and arable land. As a consequence the combination of actual and potential losses will be 50-70\% larger on clay soils 
than on sandy soils. This means that also the carbon payback time will be $50-70 \%$ higher on clay soils, compared to sandy soils. Reduction of the use of concentrates is an important sparing effect by adding maize to the animals ration (Keady et al. 2008). This effect is also calculated in the model DAIRYWISE and was an important contribution to the reduced emission per $\mathrm{kg}$ of milk (Table 2). It means that the most important effect of feeding maize is a reduction of $\mathrm{CO}_{2}$ emissions and not of methane. When maize feeding is used for animal categories that receive no concentrates, like e.g. young stock, the emission reduction should be realized via a reduced feed intake. In that case the mitigation will come from reduced methane emissions instead of reduced $\mathrm{CO}_{2}$ emissions. When the GWP of methane is $20-40 \%$ larger than we used (Shindell et al. 2009), the mitigation will also be $20-40 \%$ larger. Consequently, the carbon payback time will be $20-40 \%$ less.

Direct drilling in grassland to cultivate 1 or 2 years of maize will reduce losses of SOC and SON compared to conventional tillage and will reduce the payback time strongly. Due to the uncertainty around the effects of direct drilling in grassland, this reduction is not quantified.

As a whole, when conditions change, the losses of SOC and SON and the mitigation might change as well, and as a consequence, the carbon payback time will change. But in all cases, a large emission from land use change at the beginning of the mitigation period is only compensated after decades of mitigation.

\section{Payback time}

The ecosystem carbon payback time has been defined as the change in soil carbon due to land use change divided by the annual reduction in GHG emissions (Fargione et al. 2008). They calculated in the case of soybean biodiesel and corn ethanol payback times for grasslands of 37-93 years. Similar studies reported payback times of 0-100 years for grasslands (Gibbs et al. 2008). They calculated the lowest values for palm oil, intermediate values for sugarcane and high values for soybean. Others reported minimum values of 50 years for corn ethanol on previous grasslands (Pineiro et al. 2009). They concluded that set aside would be a better alternative.
A fast reduction of GHG emissions is essential in preventing large changes in the world's climate (IPCC 2007). This means that mitigation options should be effective immediately. From that point of view, extra maize feeding, inducing land use change, with a pay back time of 60 years is not an option.

The payback time is affected by the mitigation level and by the losses of SOC and SON when grassland is converted to cropland. On clay soils, the payback time will increase by $50-70 \%$ compared to the sandy soils, leading to pay back times of about 90-110 years.

Although the maturity of maize affects the contents and digestibility of starch, no effect on methane emissions were found when feeding this to dairy cows (Cammell et al. 2000). When feeding leads to a reduced feed intake instead of sparing concentrates, most of the mitigation come from a reduced methane emission. A $20-40 \%$ higher GWP for methane has been estimated, based on the aerosol indirect effects (Shindell et al. 2009). In the case of the illustrated farm, this hardly affects the payback time, because most of the mitigation comes from reduced $\mathrm{CO}_{2}$-emissions. But when methane emission would be the only contributor to the mitigation, the payback time would be reduced by $17-29 \%$ to 50 and 43 years respectively. This payback is still too long to contribute to a substantial reduction of greenhouse gas concentrations on the short term.

\section{Options for mitigation}

There are a two different options for mitigating methane emissions without the trade off of losing carbon stocks. The first is to grow more maize on existing arable land. This has the advantage that more crops are available on arable farms, which can lead to reduced inputs of pesticides and increased soil quality ((Nemecek et al. 2008). The possible disadvantage is that the increase of maize has to be done at the expense of food, feed or fuel crops. When growing maize on arable land will be chosen as an option on a larger scale, it is likely that the pressure on arable land will increase.

The second option is to increase the maize yield per hectare by using better varieties or by improved management, without increasing the inputs of fertilizers, pesticides and energy. 


\section{Conclusions}

Feeding extra maize as a mitigation option on intensive dairy farms is offset by ploughing grassland for maize, caused by large losses of soil organic carbon and nitrogen. Additionally, rotation of grass and maize causes high annual emissions which are so high, that even without the losses of carbon stocks, the mitigation is more than counteracted. The only option that will lead to reduction of GHG emissions on the very long term is permanent maize cropping. Ploughing grassland will lead to strong increases in GHG emissions on the short term, which is in conflict with the wish to reduce GHG emissions on the short term. The ecosystem carbon payback time for the loss of SOC and SON by ploughing grassland for maize is 60 years in the calculated situation. Changing conditions will lead to changes in the payback time of -30 to $+70 \%$. The options to avoid trade offs are maize cropping on existing arable land or increasing the maize yield per hectare.

Open Access This article is distributed under the terms of the Creative Commons Attribution Noncommercial License which permits any noncommercial use, distribution, and reproduction in any medium, provided the original author(s) and source are credited.

\section{References}

Aarts HFM, Habekotte B, Hilhorst GJ, Koskamp GJ, Van Der Schans FC, De Vries CK (1999) Efficient resource management in dairy farming on sandy soil. Neth J Agric Sci 47:153-167

Andren O, Katterer T (1997) ICBM: the introductory carbon balance model for exploration of soil carbon balances. Ecol Appl 7:1226-1236

Batlle-Bayer L, Batjes NH, Bindraban PS (2010) Changes in organic carbon stocks upon land use conversion in the Brazilian Cerrado: a review. Agric Ecosyst Environ 137:47-58

Beauchemin KA, Kreuzer M, O’Mara F, McAllister TA (2008) Nutritional management for enteric methane abatement: a review. Aust J Exp Agric 48:21-27

Bolinder MA, Andren O, Katterer T, Parent LE (2008) Soil organic carbon sequestration potential for Canadian agricultural ecoregions calculated using the introductory carbon balance model. Can J Soil Sci 88:451-460

Cammell SB, Sutton JD, Beever DE, Humphries DJ, Phipps RH (2000) The effect of crop maturity on the nutritional value of maize silage for lactating dairy cows 1. Energy and nitrogen utilization. Anim Sci 71:381-390
Carrere H, Sialve B, Bernet N (2009) Improving pig manure conversion into biogas by thermal and thermo-chemical pretreatments. 100:3690-3694

Chatskikh D, Olesen JE, Hansen EM, Elsgaard L, Petersen BM (2008) Effects of reduced tillage on net greenhouse gas fluxes from loamy sand soil under winter crops in Denmark. Agric Ecosyst Environ 128:117-126

Conant RT, Paustian K, Del Grosso SJ, Parton WJ (2005) Nitrogen pools and fluxes in grassland soils sequestering carbon. Nutr Cycl Agroecosyst 71:239-248

Conant RT, Easter M, Paustian K, Swan A, Williams S (2007) Impacts of periodic tillage on soil $\mathrm{C}$ stocks: a synthesis. Soil Tillage Res 95:1-10

Desjardins RL, Smith W, Grant B, Campbell C, Riznek R (2005) Management strategies to sequester carbon in agricultural soils and to mitigate greenhouse gas emissions. Clim Change 70:283-297

Fargione J, Hill J, Tilman D, Polasky S, Hawthorne P (2008) Land clearing and the biofuel carbon debt. Science 319:1235-1238

Garnett T (2009) Livestock-related greenhouse gas emissions: impacts and options for policy makers. Environ Sci Policy 12:491-503

Gibbs HK, Johnston M, Foley JA, Holloway T, Monfreda C, Ramankutty N, Zaks D (2008) Carbon payback times for crop-based biofuel expansion in the tropics: the effects of changing yield and technology. Environ Res Lett 3

Grant B, Smith WN, Desjardins R, Lemke R, Li C (2004) Estimated $\mathrm{N}_{2} \mathrm{O}$ and $\mathrm{CO}_{2}$ emissions as influenced by agricultural practices in Canada. Clim Change 65: 315-332

Hassink J (1994) Effects of soil texture and grassland management on soil organic $\mathrm{C}$ and $\mathrm{N}$ and rates of $\mathrm{C}$ and $\mathrm{N}$ mineralization. Soil Biol Biochem 26:1221-1231

IPCC (ed) (2006) 2006 IPCC guidelines for national greenhouse gas inventories. Prepared by the national greenhouse gas inventories programme. IGES, Japan

IPCC (ed) (2007) Climate change 2007: synthesis report intergovernmental panel on climate change, Geneva

Johnson JMF, Reicosky DC, Allmaras RR, Sauer TJ, Venterea RT, Dell CJ (2005) Greenhouse gas contributions and mitigation potential of agriculture in the central USA. Soil Tillage Res 83:73-94

Johnson JMF, Franzluebbers AJ, Weyers SL, Reicosky DC (2007) Agricultural opportunities to mitigate greenhouse gas emissions. Environ Pollut 150:107-124

Katterer T, Andren O (1999) Long-term agricultural field experiments in Northern Europe: analysis of the influence of management on soil carbon stocks using the ICBM model. Agric Ecosyst Environ 72:165-179

Katterer T, Andren O, Persson J (2004) The impact of altered management on long-term agricultural soil carbon stocks - a Swedish case study. Nutr Cycl Agroecosyst 70:179-187

Keady TWJ, Kilpatrick DJ, Mayne CS, Gordon FJ (2008) Effects of replacing grass silage with maize silages, differing in maturity, on performance and potential concentrate sparing effect of dairy cows offered two feed value grass silages. Livest Sci 119:1-11

Lovett DK, Shalloo L, Dillon P, O’Mara FP (2006) A systems approach to quantify greenhouse gas fluxes from pastoral 
dairy production as affected by management regime. Agric Syst 88:156-179

Luo J, Ledgard SF, De Klein CAM, Lindsey SB, Kear M (2008) Effects of dairy farming intensification on nitrous oxide emissions. Plant Soil 309:227-237

Nemecek T, von Richthofen JS, Dubois G, Casta P, Charles R, Pahl H (2008) Environmental impacts of introducing grain legumes into European crop rotations. Eur J Agron 28:380-393

Olesen JE, Schelde K, Weiske A, Weisbjerg MR, Asman WAH, Djurhuus J (2006) Modelling greenhouse gas emissions from European conventional and organic dairy farms. Agric Ecosyst Environ 112:207-220

Pineiro G, Jobbagy EG, Baker J, Murray BC, Jackson RB (2009) Set-asides can be better climate investment than corn ethanol. Ecol Appl 19:277-282

Roberts AM, Hudson JA, Roberts G (1989) A comparison of nutrient losses following grassland improvement using 2 different techniques in an upland area of mid-Wales. Soil Use Manage 5:174-179

Schils RLM, Verhagen A, Aarts HFM, Sebek LBJ (2005) A farm level approach to define successful mitigation strategies for GHG emissions from ruminant livestock systems. Nutr Cycl Agroecosyst 71:163-175

Schils RLM, De Haan MHA, Hemmer JGA, Van Den Pol-van Dasselaar A, De Boer JA, Evers AG, Holshof G, Van Middelkoop JC, Zom RLG (2007a) DairyWise, a wholefarm dairy model. J Dairy Sci 90:5334-5346

Schils RLM, Olesen JE, Del Prado A, Soussana JF (2007b) A review of farm level modelling approaches for mitigating greenhouse gas emissions from ruminant livestock systems. Livest Sci 112:240-251

Shindell DT, Faluvegi G, Koch DM, Schmidt GA, Unger N, Bauer SE (2009) Improved attribution of climate forcing to emissions. Science 326:716-718

Six J, Ogle SM, Breidt FJ, Conant RT, Mosier AR, Paustian K (2004) The potential to mitigate global warming with no-tillage management is only realized when practised in the long term. Glob Change Biol 10:155-160

Smink W, Pelikaan WF, Van Der Kolk LJ, Van Der Hoek KW (2004) Methane production as a result from rumen fermentation in cattle calculated bij using IPCCTier 2 method

Smith P (2008) Land use change and soil organic carbon dynamics. Nutr Cycl Agroecosyst 81:169-178
Smith WN, Grant BB, Desjardins RL, Worth D, Li C, Boles SH, Huffman EC (2010) A tool to link agricultural activity data with the DNDC model to estimate GHG emission factors in Canada. Agric Ecosyst Environ 136:301-309

Soussana JF, Allard V, Pilegaard K, Ambus P, Amman C, Campbell C, Ceschia E, Clifton-Brown J, Czobel S, Domingues R, Flechard C, Fuhrer J, Hensen A, Horvath L, Jones M, Kasper G, Martin C, Nagy Z, Neftel A, Raschi A, Baronti S, Rees RM, Skiba U, Stefani P, Manca G, Sutton M, Tubaf Z, Valentini R (2007) Full accounting of the greenhouse gas $\left(\mathrm{CO}_{2}, \mathrm{~N}_{2} \mathrm{O}, \mathrm{CH}_{4}\right)$ budget of nine European grassland sites. Agric Ecosyst Environ 121: 121-134

Steinfeld H, Gerber P, Wassenaar T, Castel V, Rosales M, De Haan C (2006) Livestock's long shadow, environmental issues and options. Food and Agricultural Organisation, Rome, p 390

Stewart CE, Paustian K, Conant RT, Plante AF, Six J (2007) Soil carbon saturation: concept, evidence and evaluation. Biogeochemistry 86:19-31

Van Der Hoek KW, Van Schijndel MW, Kuikman P (2005) Direct and indirect nitrous oxide emissions from agricultural soils, 1990-2003. Background document on the calculation method for the Dutch National Inventory Report

Van Dijk W (1997) Maize following old grassland needs little $\mathrm{N}$ and $\mathrm{P}$ (in Dutch). Pract Res 10:12-14

van Groenigen JW, Schils RLM, Velthof GL, Kuikman PJ, Oudendag DA, Oenema O (2008) Mitigation strategies for greenhouse gas emissions from animal production systems: synergy between measuring and modelling at different scales. Aust J Exp Agric 48:46-53

Vellinga TV, Van Den Pol-van Dasselaar A, Kuikman PJ (2004) The impact of grassland ploughing on $\mathrm{CO}_{2}$ and $\mathrm{N}_{2} \mathrm{O}$ emissions in The Netherlands. Nutr Cycl Agroecosyst 70:33-45

Velthof GL, Oudendag D, Witzke HR, Asman WAH, Klimont Z, Oenema O (2009) Integrated assessment of nitrogen losses from agriculture in EU-27 using MITERRAEUROPE. J Environ Qual 38:402-417

Wassenaar T, Gerber P, Verburg PH, Rosales M, Ibrahim M, Steinfeld H (2007) Projecting land use changes in the neotropics: the geography of pasture expansion into forest. Glob Environ Change Hum Policy Dimens 17:86-104 